\title{
Tawkil Traditions in the Implementation of Marriage Contract in Aceh, Indonesia
}

\author{
Imran $^{1}$, Muammar1, Jauharah', T. Azwar Aziz ${ }^{1}$, Darmawi², Hadianti ${ }^{2}$ \\ ${ }^{l}$ Lectures in Sekolah Tinggi Ilmu Syariah (STIES) Al-Aziziyah Sabang, Indonesia \\ ${ }^{2}$ Students in Sekolah Tinggi Ilmu Syariah (STIES) Al-Aziziyah Sabang, Indonesia
}

\begin{abstract}
The existence of guardians in the implementation of marriage contract has been explained in Islamic law in a clear and detailed manner. Guardian for a woman becomes one of pillar in the implementation of the marriage contract, and has a systematic sequence that starts from the main one and moves sequentially to the one after, if the one above is considered 'uzur. But the primacy of the existence of the guardian is not utilized maximally in the perception of the Acehnese people. So that most people tend to represent the implementation of the marriage contract to other people such as pious people or marriage registration officers. The parental guardian prefers to care for his guardian rights to others even though basically there is no obstacle that hinder him. The problem is the practice law of tawkil marriage in the tradition of Aceh people according to Islamic law review. The results of the study shows that the public perception of the implementation of wakalah (tawkil) marriage is based on an understanding about the ability to be brave in the implementation of the marriage contract. But their understanding is based on habits that occur in the traditions of society, not based on the results of scientific studies. Indeed, the practice of tawkil or wakalah marriage that occurs in Acehnese society does not conflict with religious law, but the implication is the erosion of the erosion of the existence of guardians and the parental guardian in a very memorable contract in the history of a human life.
\end{abstract}

Keywords : Tawkil tradition; marriage contract; Aceh.

\section{Introduction}

One of the cases that often occur in the implementation of marriage contracts in Aceh is the guardian of a woman representing the implementation of the marriage contract to the pious or other people. Even though the parental guardian is more important than other people in the implementation of the marriage contract. The public's perception of the primacy of the parental guardian in the implementation of the marriage contract has been blurred due to the increasing number of tawkil traditions in the implementation of the marriage contract. Many the parental guardian those who are reluctant to marry women who are within their authority just because they are embarrassed and not brave or other reasons that are very simple.

Guidelines for the implementation of marriage contracts in Indonesia have been made through KHI (Compilation of Islamic Law). ${ }^{1}$ This book is a reference for officers to get uniformity of implementation and similarity of perceptions regarding the procedure of marriage. In the book clearly stated that the marriage guardian is a pillar that must be fulfilled for the prospective bride who acts to marry her. ${ }^{2}$ And in the book also mentioned, that the guardian in this case is divided into two groups, namely parental guardian (nasab) and magistrate guardian (hakim). Then in the following article it is stated that the guardian of the $n a s a b$ consists of four groups in the order of position, the one group takes precedence, and the

\footnotetext{
${ }^{1}$ A reference book for the implementation of a marriage contract that is made as a patron for the implementation of the marriage contract for Marriage Record Employees (PPN) at various levels. The agency is called the Office of Religious Affairs (KUA).

${ }^{2}$ Article 19 Compilation of Islamic Law.
} 
other group according to whether or not the arrangement of kinship is closely related to the prospective bride. ${ }^{3}$ Determination of guardians in the implementation of marriage contracts based on the size of kinship is evidence of the importance of the implementation of the degree of primacy for the prospective bride guardians in the implementation of the marriage contract.

Marriage contracts from the dimensions of sacredness are special contracts compared to other contracts such as buying and selling, pawning and others. In addition to the marriage contract, it can be done several times without limits, while the marriage contract is only limited to four times, because most men are only permitted by four wives. Because in the concept of shariah a man is only able to take maximum responsibility for four wives. ${ }^{4}$ Marriage contract in Islam is considered as a matter that must be handled with care, because it will have legal implications for various other things caused by marriage, such as nafaqah, inheritance and also the sustainability of happy households. One of the most important elements of the marriage contract is only a parental guardian (nasab). Only a prospective bride has the right to marry a woman in her guardianship. This is only given by Islam to guardians, because women cannot marry themselves. If a woman marries herself, then her marriage is not legal. ${ }^{5}$ But in reality, the marriage guardian who has the right to marry sometimes loses his guardianship due to certain matters, which requires his guardianship to move to another guardian of marriage in the hierarchy that is in the ring further than that.

When viewed from aspects of virtue and validity. The aspect of virtue is often overlooked, which is sometimes at very simple considerations. In the hierarchy of authority (tartibul awliya '), parental guardian (nasab) is more important than other guardians. ${ }^{6}$ This is based on a number of considerations including the closeness of the bride and her guardian, as well as the authority given by the religion to her. Parental guardian (nasab) is the party who is always responsible for everything that has happened and will happen to women, and those who always interact in various family activities. Because of that Islam gives full authority to the parties who have been given the authority of the guardian. In this case, the care and seriousness of the guardian is needed in the marriage contract. The guardian is not justified in assuming that the marriage contract is only a matter of responsibility and considers it lower than the contract other contract But the future of a prospective bride and the level of readiness must also be guaranteed well. Guardians who feel that this is their responsibility, it will not be easy to give up that responsibility to others, as a form of responsibility towards the mandate that has been given to him.

In reality that occurs among the Acehnese, the implementation of the marriage contract is often represented to other people for various reasons, such as incompetent guardians, or guardians do not dare to appear before the general assembly, but the most are lack of understanding that they are more entitled than those who others to carry out marriage contracts for prospective brides who are under their authority. As a result, the trustees easily transfer their authority to the representative. The person appointed by the prospective brides of guardian to marry the woman, usually a person who is considered sacred or pious, this can be understood

\footnotetext{
${ }^{3}$ Article 20-21 Compilation of Indonesian Islamic Law (KHI).

${ }^{4}$ Al-Quran, Surat an-Nisa, verse 3.

${ }^{5}$ In the hadith narrated by Imam Ahmad mentioned

${ }^{6}$ In fact, among the Guardians of the Nasab itself the serial number applies, the one group takes precedence over the other group, according to whether or not the kinship arrangement with the prospective bride is closely related. See: Mohd. Idris Ramulyo, S.H., M.H., Hukum Perkawinan Islam, Jakarta : Bumi Aksara, 2002, p. 74
} 
from the term often spoken among Acehnese people for someone who has reaching the age of marriage with the phrase "pajan nuemat jaroeu ureng malem atau kaleuh neumat jaroe ureung malem?"7. Such habits can shift the primacy of the patronage both from the aspect of his responsibility and the understanding of the primacy of the guardian in marrying women who are under his authority. Slowly this habit has become a life guide that makes understanding about the primacy of the parental guardian (nasab) blurred. ${ }^{8}$

Tawkil marriage from the guardian to the representative there is no prohibition in Islamic religion, but the position of the parental guardian (nasab) is more important than the other is irrefutable, in fiqh books it is often stated about the primacy of the parental guardian (nasab) in marriage. Directly with marriage that is legitimized by religion. The practice of transferring authority from the patriarch to the representative is seen from the reality of society aimed at achieving virtue. This is often heard the phrase to take blessings or blessings from people who are considered holy. Seen from the "tabarruk" aspect, ideally bertabarruk" 9 With more important religious rules. Because it is a religious recommendation, and the contract is directly related to the teachings of religion. Here there is a mistake in understanding the primacy of the guardian in the practice of the Acehnese people. As a result, it was rarely found in villages where the parental guardian (nasab) married the prospective bride themselves, even though they still wait for the chance for the pious person to marry her even though must change days or even months.

Unlike tawkil is talqin, which is guiding the guardian of marriage in carrying out the marriage contract by reading word by word of marriage contract pronunciation. However, talqin culture is rarely practiced by the community, perhaps because it is still considered a stranger. Indeed, the Talqin method can be an alternative for guardians who are less ready to carry out marriage contracts before moving to the way of tawkil, because they can maintain the rights of the guardian and also do not hinder other intentions to be achieved in the marriage contract.

\section{Review of Literatures}

\subsection{The Term of Talqin in the Al-Quran and Hadith}

The term "talqin" is not found in the Al-Quran in the form of masdar, namely "talqin"

\footnotetext{
${ }^{7}$ This phrase in Acehnese is often spoken to young people who have reached the age of marriage. The meaning of the phrase is "have you shaken hands of the pious?" This expression arises because usually people who carry out marriage contracts are pious people based on wakalah (tawkil) guardians of prospective brides to marry women who are under their authority.

${ }^{8}$ Values about norms start from the environment. The cultural part that directly affects the personality of an individual person in general, among others:

a. Special culture on the basis of regional factors.

b. How to live in a typical community environment, such as living habits in the city or in the village.

c. Special culture based on social class.

d. Special culture on the basis of religion.

e. Job or expertise (profession)

9 If viewed in terms of linguistic meaning, seek blessings. Blessing is increasing and developing in terms of goodness. Thus, the meaning of tabarruk is to seek additionality in kindness. When people say "looking for blessings on something" means to take the value of goodness from something that was. On that basis, the definition of tabarruk from the term is, to expect blessings from something or other things that Allah Subhânahu wata'âlâ has given special features and position to him. The tabarruk propositions are:
}

$$
\text { اللهم إني أسألك و أتوجه إليك بنبينا محمد نبي الرحمة يا محمد إني أنوجه بك إلى ربي في حاجتي لتقضى لي }
$$


or in other forms such as fi'il mudhari ', fi'il madhi, fi'il amar, isim fa'il and others of all forms -shape words in Arabic vocabulary. ${ }^{10}$ As for the hadith, the term talqin the author found in several hadiths in several different forms, for more details the authors include some of these hadiths, First:

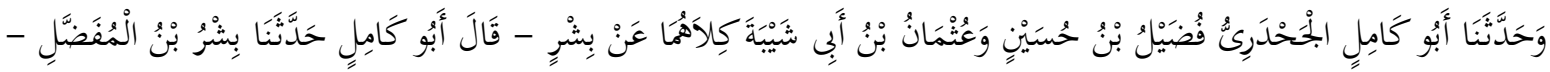

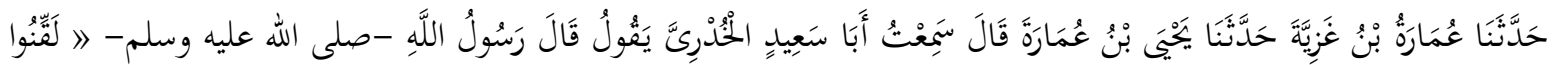

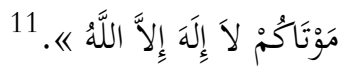

The above hadith is one of the hadiths the author quoted from the authentic Muslim Hadith Book. The term talqin in the hadith is written in the form of plural amar, namely "Laqqinuu" meaning: Teach by all of you. In the authentic Muslim book, this term is found in two different hadiths, the first hadith narrated by Abu Hurairah and the second hadiths narrated through thariq Aba Sa'id al-Khudhriy. Second:

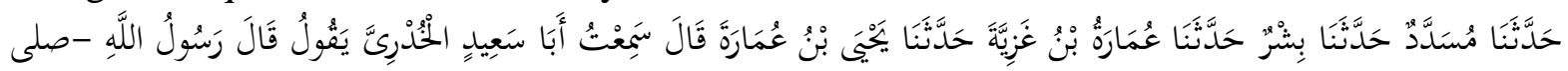

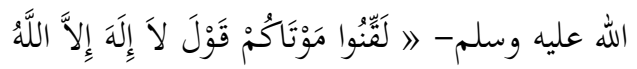

The hadith above the author quoted from the book of Hadith Sunan Abu Daud, in the book only found one hadith which contained the term of talqin in the plural as well. This hadith differs slightly from the editions of the first hadith because of this hadith after the term "laqqinuu" plus the term "qaulakum". Third:



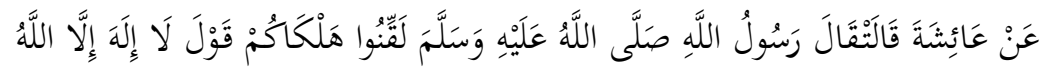

This hadith take from the hadith of Sunan Nasai. The term of talqin is written in the form of plural fi'il amar as well, similar to those found in the previous two hadiths. Judging from the hadith editorial text, there are differences from the previous two hadiths. This hadith, the term "Mautaakum" is written with "halkaakum", but does not affect the difference in meaning. However, if you look at the sanad of this hadith originating from Sayyidah 'Aisyah is different from the two previous hadiths originating from Abu Hurairah and Aba Sa'id al-Khdriy.

The term of talqin in the hadith are all in the form of amar jama' both those found in our three that we have mentioned and in other hadiths. The difference is only in words or term after "laqqinuu". The next difference is in the sanad of the hadith.

The author concludes that talqin vocabulary, is not a foreign vocabulary in hadith literature, so that this vocabulary can be developed into a concept in dealing with community

\footnotetext{
${ }^{10}$ The author has traced the sentence in the Qur'an by using the search application found in the Makatabah Syamilah program.

${ }^{11}$ This hadith is very short, namely "laqqinu mawtakum qaula la ilaha illallah " means "read "la ilaha illallah to the person who almost died", while the very long one is the sanad. View more, Muslim Bin Hajjaj anNaisabury, Shahih Muslim, Penerbit : Mauqi' Wuzaratul awqf al-Mishriyyah. TT.J. 6, p. 48.
} 
practice problems with regard to the implementation of marriage contracts amid the rampant culture of marriage is a job in the form of applying a marriage contract to guide the guardian who is not able to read the marriage contract in the marriage contract assembly. Talqin should be carried out by pious people who are considered to have sacredness and superiority by the bride's guardian.

\subsection{The Perspective of Ulema about Talqin}

The ulema have introduced Sunnah talqin through the results of their ijtihad towards the existence of the Sunnah Talqin legal position of people who have died. They have explored the hadith content "laqqinuu mautakum qaula laa ilaaha illallah", so they concluded, if there were people who died circumcised to be accused. Ijtihadulama has been practiced by the community in the first two forms: reading the surah yasin when people suffer from severe pain that has no hope of recovery. As mentioned by Al-Razi in his Tafsir.

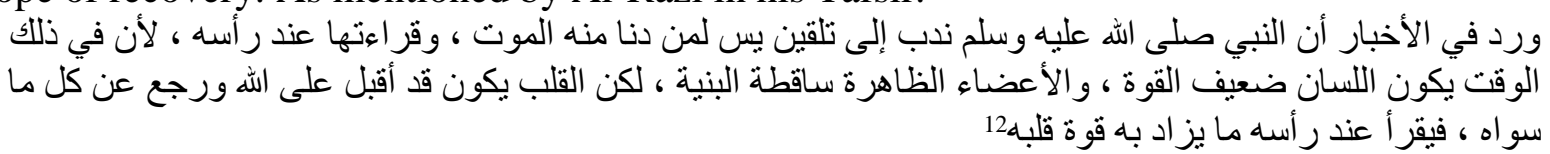

Meaning: Hadith of the Messenger of Allah has come about talqin recommendation of surah Yasin to the person who is approaching death, and read it near the head, because at that time, the tongue is weak, the end of the body does not function, but the heart is concerned about facing God, then read something that can strengthen the strength of his heart.

Second: read talqin when the person dies just finished the funeral. Talqin is read to teach people who have died because at that time the soul of a deceased person was returned to his body by Allah, so that he could hear what was said. This sunnah is generated from the istimbath of the hadith of the Prophet Muhammad, as mentioned in the discussion on number 1 point B, namely the hadith "Laqqinu Mautaakum".

\section{Discussion}

\subsection{The Position of the Marriage Guardian (Nasab) in the Marriage Contract}

The guardian of the nasab gets a high position in marriage, in the books of fiqh when discussing the marriage guardian, it always starts by discussing the guardian of the nasab. Even there is an opinion that says, that there is no fair requirement for the guardian of marriage because authority in matters of marriage is built on blood relations, biological relations can produce perfect affection for the muwallah, where love is the first problem that needs to be guarded by religion in the marriage contract. As for affection it is in the person who is just and also in the person who is fasiq. This opinion confirms that the direct role of the patriarch is highly expected by religion in the marriage contract.

The meaning of the parental guardian (nasab) is a person consisting of a prospective bride's family and has the right to become a guardian. The order of the patriarch is: (1) Father, grandfather (father of the father) and so on, (2), biological brothers (a thousand), (3), brothers and sisters, (4), children male from biological brother, (5), son from brother to father and so on, (6), uncle (brother of biological father), (7), uncle (brother of father ) father, (8), uncle's

\footnotetext{
${ }^{12}$ Fakhruddin ar-Razi, Tafsir Mafatihul Ghaib, J. 13, p. 99. The term talqin, Yasin is only found in Tafseer Mafatihul Ghaib. Whereas in other interpretations the writer does not find it. Perhaps the other interpreters did not use the term Talqin Yasin.
} 
biological son, (9), father's uncle's son and so on down.

The above order must be carried out in an orderly manner, meaning that the right to become a guardian is father, if the father has died or does not meet the requirements, then the guardian moves to his grandfather and if the grandfather has died or has not fulfilled the specified conditions, the guardian falls to his grandfather and so on to the top. That is so on until the last sequence.

There are several things that make the guardianship closer can be replaced by a guardian who is further away, namely: A more entitled guardian does not exist, a guardian who has the right has not been baligh, who has the right to suffer madness, a guardian who has the right to be senile because of an old guardian more entitled to mute cannot be accepted signal, the guardian has the right to not be Muslim while the woman is Muslim. If a more entitled guardian does not exist, then the substitute is a guardian further by taking into account the order as stated in the quote. If it occurs outside of these provisions, the guardian of the marriage will fall to another guardian, the guardian of the sultan or magistrate. Parental guardian (nasab) is divided into two. First, the parental guardian (nasab) who has the right to determine the marriage and with whom a woman must marry. This force is called the mujbir guardian. The Guardian of the Mujbir who has the right to marry his daughter by not having to ask permission beforehand for his daughter must fulfill several conditions, namely: a. there was no hostility between the mujbir guardians and the girl. b. Sekufu' between a woman and her future husband. c. The prospective husband is able to pay the dowry. d. Candidates for unblemished husbands who endanger association with him, such as blind people. Second, guardians who do not have the right to force unmarried brides or in fiqh discussion are called (bikrun), while widowed women (tsaybun) are not given forced rights to guardians.

\subsection{Wakalah Traditions (Tawkil) in the Implementation of Marriage Contract in Aceh}

Tawkil marriage in Aceh can be said to have taken root and has become a culture, this can be seen from the empirical reality that occurred in the lives of the people of Aceh. The lower middle class people from the aspect of knowledge generally represent the marriage of their children to people who are considered more pious, because they want to get the virtue or blessing of the pious people. Whereas in the provisions of the shariah the guardian of the parental (nasab) is always more important than the others in terms of the implementation of the marriage contract. In common sense too, actions deemed important by someone as long as he can do it are difficult to let go to others except in abnormal conditions. ${ }^{13}$ Awareness of the virtues and prudence in carrying out marriage contracts is inversely proportional to the awareness of the primacy and caution in carrying out other contracts. This has an impact on the responsibility of the patronage towards women who are within their authority and also has the effect of weakening the quality of the relationship between the guardian and the wizard.

Sunnah that has developed in society, usually raises a misunderstanding in the midst of ordinary people. It has happened a lot in the midst of ordinary people, women who still have guardianship, but still come to pious people to ask to marry themselves. When the pious person refuses because there is a patriarch who is still alive, the woman even slanders the pious person,

\footnotetext{
${ }^{13}$ There is one Hadih Maja (proverb) of the Acehnese who has become their philosophy of life "meunye kon anoe, leuhob, menye kon droe, mandum gob", the meaning is: if it is not oneself who do something, then they will not get satisfaction. The Acehnese people to carry out all transactions and their own obligations. Finally, this philosophy lacks life in the implementation of the marriage contract.
} 
if his family wants to be married while he does not want it. So that the bad impact goes back to the pious people. Caused by the practice of wild qadhi. But the effect that is seen to the surface when every marriage ceremony is always an official person who is married can also be official information that is wrongly captured by the public that the legitimacy of the validity of marriage is not in the guardian but in the pious person.

The effect of wild qadhi is not much, because the practice of wild qadhi is not free, and the practice is also limited. The practice of insubstantial marriage has occurred almost every time there is a marriage contract. Moreover, illiteracy is carried out without witnessing and not in public. The marriage contract is carried out in public, while the marriage contract is carried out not in public. This practice creates a misperception of the public about the authority of the guardian in the marriage contract. The shift takes place slowly but real.

Thinking in the scope of society and constitutionality, of course should not only consider the legitimacy of the law which stipulates change or permissibility, but the gaps that can lead to public error must also be pro-active to be narrowed, so as not to drain a lot of energy to rectify a long-standing mistake tradition, especially if you allow the emergence of more complicated new problems. One real example, the marriage contract carried out by a representative but recorded in state documents is carried out by his bride guardian. This case is very likely to cause some negative effects, namely:

1. Opening the gap of ignorance in personal responsibility, because it is accustomed to breaking away from work that should be done alone.

2. The chance for the parental guardian (nasab) to sue, if the mayor disputes that he is not the one who married the child but why in the recording was made he married, why did the government not make a note as is. This problem is difficult to provide understanding to guardians who have such a paradigm of thinking, especially if tawkil contract there are no witnesses,

3. Weakening the recording program. Whereas the current marriage registration has become the most important thing because it influences other deeds, when the government must record the actual ones, it will provide logical reasons to legalize insubordination which may have occurred in some citizens.

4. Reducing enthusiasm and loyalty in the state, loyalty in the state cannot be built immediately, maturation of society requires time and also the practice of the state is essentially a very good learning for the community. Community trust in the country is built on the prevailing state rules and systems. Systems and rules and good practices in carrying out state rules are the right solution to build the spirit of the people to love and be loyal to the country.

Seeing the development of the tawkil culture of marriage in the reality of society, two fundamental things have been found that make tawkil marriage difficult to seem less effective and can lead to misunderstanding of the community towards the marriage contract. The two things are: First, the presence of the Guardian in the assembly of the contract. In other contracts, muwakkil are often absent from the assembly of the contract, either because they are deemed not necessary to attend or because there is something that makes the muwakkil unable to attend. As for the marriage contract process, they don't feel satisfied if they don't attend the contract assembly. Second, marriage contract transactions are not difficult and difficult actions so transactions must be carried out by a truly professional person. If the marriage contract is included in an exclusive act, then the shariah will not make this the responsibility of all trustees, both middle and lower middle class. But because the reality that develops in society has made 
a marriage contract a contract that has a level of sacredness over other contracts. Finally the marriage contract becomes an expensive shariah and has high economic value. So that it becomes a heavy sunnah for Muslim youth today.

\section{Conclusion}

The tawkil tradition of marriage has been entrenched in the midst of society, especially in Aceh, even competent and capable people, also involved in the implementation of the bride's marriage contract under his authority to others. Seen from the aspect of formal law, there is nothing that is contradictory, but it is assessed from the aspect of the impact and the effect on the guardian's awareness of his authority is very impactful. The law of tawkil marriage is mubah and the law of talqin marriage is mubah also. The tawkil tradition of marriage in Acehnese society is more influenced by the prevailing habits in the community, this habit has become a guideline in the implementation of the marriage contract in the tradition of the community. Ideally, a parental guardian (nasab) should not rush to transfer his duties to others if he is able to do it himself. If also the parental guardian (nasab) is incapable, it should take the talqin effort first before directly choosing anger. However, if the guardian has other intentions such as taking blessings or (sempena $)^{14}$ from a pious person, it can be that the pious person mentions the guardian in the assembly of the contract. So that, all virtues from both the parental guardian (nasab) and pious people will be obtained.

\section{References}

Abu Abdurrahman Ahmad an-Nasa-I, Sunan an-Nasai, Beirut : Darl Ma'rifat, $1420 \mathrm{H}$, Dirjen Bimas Islam and Urusan Haji, Pedoman Fiqh Munakahat, Jakarta: 2000

Fakhruddin ar-Razi, Tafsir Mafatihul Ghaib, TT

H. Idrus Ahmad, Fiqh al-Syafi'iyah: Fiqh Menurut Mazhab Syafi'i, Widjaya, Jakarta: 1969

Ibnu Rusydi, Bidayatul Mujtahid, edisi terj. Analisa Fiqih Para Mujtahid, Jakarta : Pustaka Amani, 2002

Kompilasi Hukum Islam dalam Lampiran Inpres Nomor 1 Tahun 1991 tentang Penyebarluasan Kompilasi Hukum Islam

M. Yunus, Hukum Perkawinan dalam Islam menurut Empat Mazhab, Jakarta: PT. Hidakarya Agung, 1996.

Muhammad Ibn Isma'il al-Kahlany, Subul al-Salam Syarh Bulug al-Maram min Jam'i Adillah al-Ahkam, Thoha Putera, Semarang: t.th

Muslim Bin Hajjaj an-Naisabury, Shahih Muslim, Publisher : Mauqi' Wuzaratul awqf alMishriyyah. TT.

Musthafa al-Khin and Musthafa al-Bugha, al-Figh al-Manahajy, Damaskus : Dar al-Qalam, 1430. H/ 2009.

Pedoman Pegawai Pencatat Nikah, Proyek Peningkatan Tenaga Kegamaan Direktorat Jenderal Bimbingan Haji Departemen Agama R.I, Jakarta, 2004.

Peraturan Menteri Agama No. 2 Tahun 1987 tentang Wali Hakim

Sulaiman bin al-asy'as Abu daud, Sunan Abu Daud,Darl Fikr, TT.

${ }^{14}$ Seumpena is a vocabulary in the Acehnese language which means blessing. 
Syahabuddin al- Qalyubiy dan 'Amirah, Qayubi wa 'Amirah, Toha Putra Semarang, TT.

Taqy al-Din Abu Bakr Ibn Muhammad al-Husainy, Kifayah al-Ahyar fi Halli Ghayat alIkhtishar, Juz II, Semarang: t.th

Team Kajian Ilmiyah Abituren, Simbiosis Negara dan Agama, Lirboyo Kota Kediri : Purna Siswa Aliyah, 2007.

UU Nomor 1 Tahun 1974 tentang Pekawinan

Wahbah Al-Zuhaily, al-Fiqh al-Islamy wa Adillatuh, Juz IV. Dar al-Fikr, Beirut: 1989

Wahbah Al-Zuhaily, al-Fiqh al-Islamy wa Adillatuh, Juz VII: al-Ahwal al-Syahshiyyah, Dar Al-Fikr, Beirut: 1989. 